\title{
Nitroxygenation of Quercetin by HNO
}

\author{
Xiaozhen Han, Murugaeson R. Kumar, and Patrick J. Farmer* \\ Department of Chemistry and Biochemistry, Baylor University, Waco, TX 76798
}

\section{ARTICLE INFO}

\section{Article history:}

Received

Received in revised form

Accepted

Available online

\section{Keywords:}

Quercetin

Nitroxyl/HNO

Nitroxygenation

Single electron transfer

\section{ABSTRACT}

The flavonol quercetin undergoes both enzymatic and non-enzymatic reactions with nitroxyl ( $\left.\mathrm{HNO} / \mathrm{NO}^{-}\right)$, similar to analogous reactions with dioxygen, but in which $\mathrm{N}$ is regioselectively found in the ring-cleaved product. Here we report on kinetic and thermodynamic analysis of the non-enzymatic nitroxygenation reaction in water, which is orders of magnitude faster than the comparable dioxygenation. The second order rate constants were determined from variable temperature reactions, which allowed determination of the reaction activation enthalpy $\left(\Delta H^{\neq}=9.4 \mathrm{kcal} / \mathrm{mol}\right)$, entropy $\left(\Delta S^{\neq}=-8.3\right.$ $\mathrm{cal} / \mathrm{mol} \mathrm{K})$, and free energy $\left(\Delta G^{\neq}=11.8 \mathrm{kcal} / \mathrm{mol}\right)$. The determined standard state energy $\left(\Delta G^{\circ}\right)$ and activation free energy, as well as the low entropic energy of reaction, are consistent with a proposed single electron transfer (SET) rate determining step.
Quercetin and other flavonoids are antioxidants found in fresh fruits and vegetables that have been shown to play an important preventative role in cardiovascular diseases and aging. ${ }^{1-3} \mathrm{~A}$ number of enzymes have been found which decompose flavonoids by reaction with dioxygen, Scheme 1.,5 The same reaction occurs non-enzymatically, though typically at higher $\mathrm{pH}^{4}$

\section{Scheme 1}

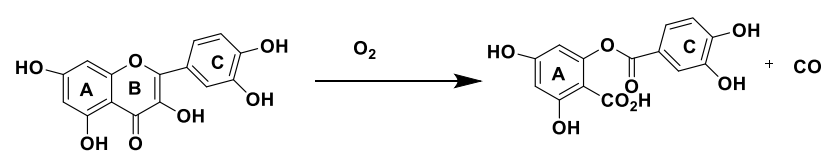

In a series of mechanistic studies, the Speier group proposed that in organic solvents the non-enzymatic reaction proceeds by an way of a rate-limiting single electron transfer (SET) between the deprotonated flavonol and oxygen, but in protic solvents a second slower bimolecular reaction competes. ${ }^{5}$ Metal complex models for the enzymatic reactions have also examined by Speier $^{6}$ and others ${ }^{7,8}$ In both the free or metal-bound nonenzymatic oxygenations, the reactions are typically observed at temperatures above $70{ }^{\circ} \mathrm{C}$, with reported activation free energies of greater than $24.1 \mathrm{kcal} / \mathrm{mol}^{5 \mathrm{a}, 6 \mathrm{f}}$

Nitroxyl, HNO, is the reduced and protonated congener of $\mathrm{NO}$, which is isoelectronic with singlet $\mathrm{O}_{2}$. HNO displays biological effects distinct from that of NO, for example as an enzyme inhibitor ${ }^{9}$ and ionotropic agent that may be used in the treatment of heart failure. ${ }^{10}$ Recently, we reported the unprecedented substitution of HNO for dioxygen in the activity of Mn-substituted Quercetin Dioxygenase, Mn-QDO, resulting in the incorporation of both heteroatoms of HNO regioselectively into the product, Scheme $2 .{ }^{9}$ In these reactions, HNO is generated in situ from a precursor, and in the presence of enzyme and substrate, and like dioxygenation, cleaves the central Oheterocyclic ring to release $\mathrm{CO}$. The reaction likely proceeds through an analogous depsidic product 2 , which decomposes to give the observed 2,4,6-trihydroxybenzoic acid and 3,4dihydroxybenzonitrile products. Importantly, like dioxygenation, a non-enzymatic nitroxygenation of quercetin with HNO proceeds at high $\mathrm{pH}$ yielding the same regioselective products, again suggesting the deprotonated quercetinate anion is the dominant reactant.

\section{Scheme 2}<smiles>O=c1c(O)c(-c2ccc(O)c(O)c2)oc2cc(O)cc(O)c12</smiles>

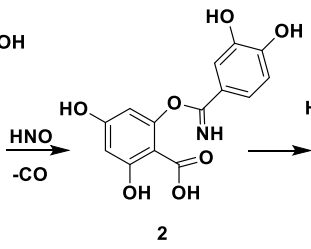<smiles>N#Cc1ccc(O)c(O)c1</smiles>

The coupling of HNO to an enolic carbon center is similar to the so-called nitroso aldol reactions, NA, in which nitroso compounds couple with activated ketones and aldehydes yielding both O- or N-bound adducts, Scheme 3. ${ }^{11}$ The early examples of these aldol condensations utilized nitrosobenzene and strongly activated enolates or silyl enol ethers, typically yielding N-bound hydroxyamino products. ${ }^{12-14}$ More recent work by Yamamoto and coworkers have shown a much wider scope of NA reactivity, ${ }^{15}$ with Lewis-acid catalysis yielding O-bound aminooxy adducts. ${ }^{16-17}$ These reactions are proposed to occur through bimolecular nucleophilic attack, rather than outersphere SET. 
Scheme 3

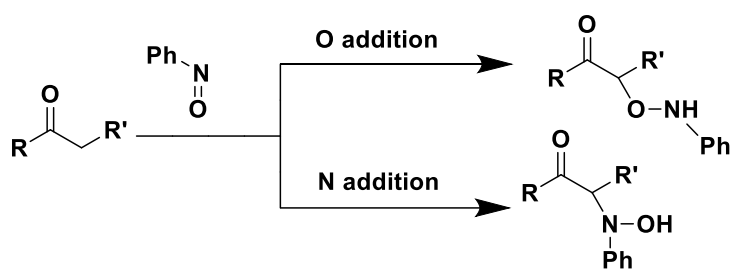

In this report, we investigate the kinetics and thermodynamics of the non-enzymatic reaction to address questions regarding the mechanism of nitroxygenation. Reactions between quercetin and HNO were monitored by the decay of the quercetin absorption band with $\lambda_{\text {max }}$ of $400 \mathrm{~nm}$, as shown in Figure 1. The majority of experiments were run at $\mathrm{pH} 8.0$ in phosphate buffer, conditions at which quercetin $(\mathrm{pKa}=7.1)^{18}$ is almost $90 \%$ deprotonated and compatible with the use of Angeli's Salt (AS) as a stable source of HNO. Under analogous conditions, no side reaction of quercetin with the byproduct $\mathrm{NO}_{2}^{-}$, was seen on the timescale of the measured reactivity.

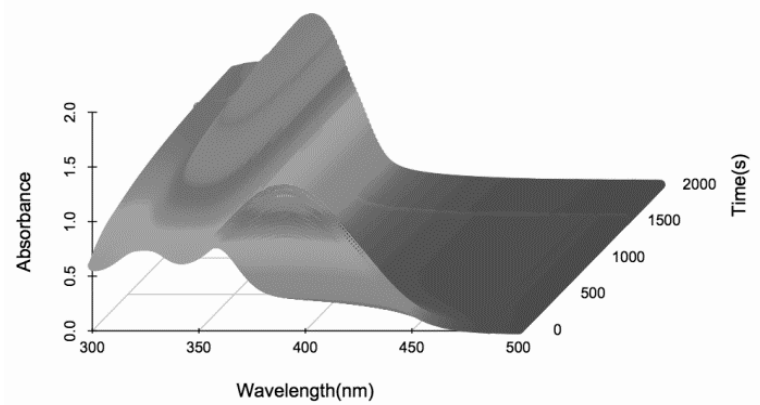

Figure 1. Absorbance spectra obtained over the course of reaction of quercetin $(0.04 \mathrm{mM})$ with HNO donor Angeli's salt $(1.00 \mathrm{mM})$ in $\mathrm{pH} 8.0$ sodium phosphate buffer at $298 \mathrm{~K}$.

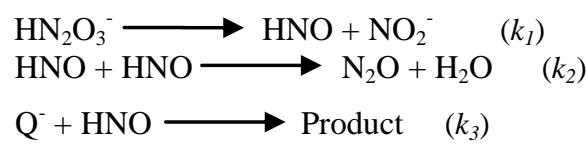

The reaction sequence in Equations 1-3 was used to model the kinetic data. These reactions are complicated by the slow release of $\mathrm{HNO}$ from AS, and its competitive dimerization forming $\mathrm{N}_{2} \mathrm{O} .{ }^{19}$ The temperature dependence under our conditions for the first-order rate constant $k_{1}$ for Equation 1 was obtained following the loss of absorbance of Angeli's salt at $250 \mathrm{~nm}$, in both $\mathrm{H}_{2} \mathrm{O}$ and $\mathrm{D}_{2} \mathrm{O}$ solutions. A literature value for the bimolecular rate of Equation 2, $k_{2}=8 \times 10^{6} \mathrm{M}^{-1} \mathrm{~s}^{-1}$, was assumed unchanged under these conditions. ${ }^{9,19}$

Table 1. Temperature dependence of AS decomposition

\begin{tabular}{lll} 
& \multicolumn{2}{c}{$k_{1}\left(\mathrm{~s}^{-1}\right)^{\mathrm{a}}$} \\
\cline { 2 - 3 } $\mathrm{T} / \mathrm{K}$ & $\mathrm{HNO}$ & $\mathrm{DNO}$ \\
\hline 288 & $5.0 \times 10^{-4}$ & $4.0 \times 10^{-4}$ \\
293 & $7.0 \times 10^{-4}$ & $6.0 \times 10^{-4}$ \\
298 & $1.8 \times 10^{-3}$ & $1.5 \times 10^{-3}$ \\
303 & $2.6 \times 10^{-3}$ & $2.3 \times 10^{-3}$ \\
308 & $3.4 \times 10^{-3}$ & $2.8 \times 10^{-3}$ \\
\hline a experimental variance within 5\%.
\end{tabular}

${ }^{\mathrm{a}}$ experimental variance within $5 \%$.
The temperature dependence of the second-order rate constant of Equation 3, $k_{3}$, was obtained by converting absorbance data to concentration vs time and then fitting the data to the reaction sequence using REACT for Windows, Version 1.2, Figure $2 .^{20}$ Table 2 gives the determined rate constants for analogous reactions of $\mathrm{HNO}$ and $\mathrm{DNO}$, the latter being the assumed reactant in $\mathrm{D}_{2} \mathrm{O}$ solution.

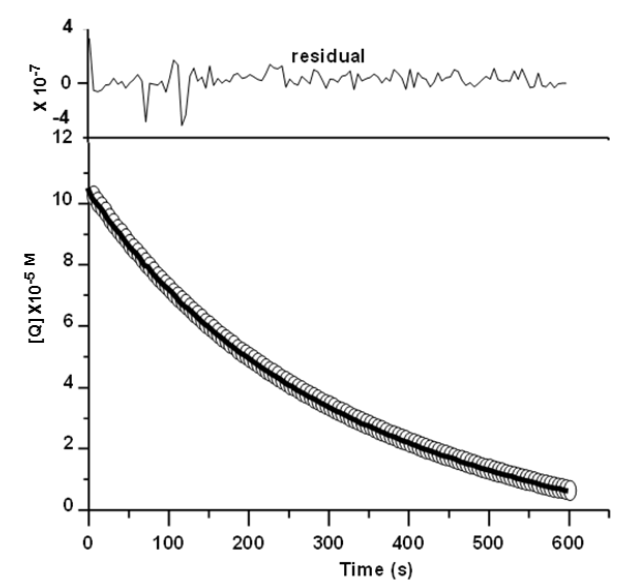

Figure 2. Overlay of modeled (dot) and experimentally-derived (dash) concentrations for a typical reaction, with residual plot above.

Table 2. Temperature dependence of $k_{3}$

\begin{tabular}{ccc} 
& \multicolumn{2}{c}{$k_{3}\left(\mathrm{M}^{-1} \mathrm{~s}^{-1}\right)^{\mathrm{a}} \times 10^{4}$} \\
\cline { 2 - 3 } $\mathrm{T} / \mathrm{K}$ & $\mathrm{HNO}$ & $\mathrm{DNO}$ \\
\hline 288 & $0.782( \pm 0.15)$ & $0.418( \pm 0.13)$ \\
293 & $1.10( \pm 0.05)$ & $0.573( \pm 0.08)$ \\
298 & $1.34( \pm 0.09)$ & $0.852( \pm 0.07)$ \\
303 & $1.85( \pm 0.07)$ & $1.32( \pm 0.05)$ \\
308 & $2.49( \pm 0.12)$ & $2.06( \pm 0.09)$ \\
\hline a experimental variance is within 5\%, average of three trials (error \\
in parenthesis).
\end{tabular}

Using the data in Table 2, the activation enthalpy $\left(\Delta H^{\neq}\right)$and activation entropy $\left(\Delta S^{\neq}\right)$for the reaction were derived from Eyring plots of $\ln \left(k_{2} / T\right)$ versus the reciprocal of the absolute temperature $(1 / T)$, respectively, and are given in Table 3 for reactions in both $\mathrm{H}_{2} \mathrm{O}$ and $\mathrm{D}_{2} \mathrm{O}$. Analysis of the variable temperature kinetic data on this reaction obtains an activation free energy $\Delta G^{\ddagger}$ of $11.8 \mathrm{kcal} / \mathrm{mol}$, shown in Table 3 . The kinetic isotope effect, KIE, derived from rate constants obtained in $\mathrm{H}_{2} \mathrm{O}$ and $\mathrm{D}_{2} \mathrm{O}$ solutions is 1.92 at $293 \mathrm{~K}$. This value suggests, as well as the relatively small entropic energies of activation, suggest that no bonds are made or broken in the rate-determining step.

Table 3. Determined activation parameters at $20{ }^{\circ} \mathrm{C}$ for Equation 3.

\begin{tabular}{ccccc}
\hline & $\begin{array}{c}\Delta H^{\ddagger} \\
\mathrm{kcal} / \mathrm{mol}\end{array}$ & $\begin{array}{c}\Delta S^{\ddagger} \\
\mathrm{cal} / \mathrm{mol} \mathrm{K}^{\mathrm{a}}\end{array}$ & $\begin{array}{c}-\mathrm{T} \Delta S^{\ddagger} \\
\mathrm{kcal} / \mathrm{mol}\end{array}$ & $\begin{array}{c}\Delta G^{\ddagger} \\
\mathrm{kcal} / \mathrm{mol}^{\mathrm{b}}\end{array}$ \\
\hline HNO & $9.38( \pm 0.04)$ & $-8.27( \pm 0.03)$ & 2.42 & 11.80 \\
DNO & $13.61( \pm 0.02)$ & $5.07( \pm 0.04)$ & -1.48 & 12.13 \\
\hline a From
\end{tabular}

${ }^{\mathrm{a}}$ From intercepts of the Eyring plots.

${ }^{\mathrm{b}}$ From the equation $\Delta G^{\ddagger}=\Delta H^{\ddagger}-\mathrm{T} \Delta S^{\ddagger}$.

$$
\mathrm{Q}^{-}+\mathrm{O}_{2} \longrightarrow \text { Product }\left(k_{4}\right)
$$

For comparison, the bimolecular rate constant of dioxygenation, $k_{4}$, at $293 \mathrm{~K}$ is $0.46 \mathrm{M}^{-1} \mathrm{~s}^{-1}$, ca. $10^{4}$ slower than that of nitroxygenation. Likewise, the reported enzymatic dioxygenation reaction of quercetin by Mn-QDO was ca. $10^{4}$ slower than the analogous nitroxygenation. ${ }^{9,21}$ Thus nitroxygenation appears to be fundamentally and significantly more facile than dioxygenation in these reactions. 


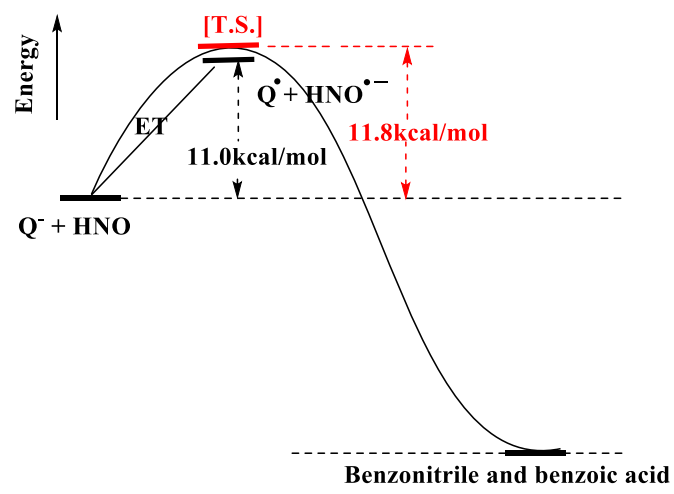

Figure 3. Reaction coordinate diagram for Equation 3 showing determined activation energy in red, and calculated value for initial outer-sphere electron transfer mechanism.

$$
\Delta G^{\mathrm{o}}=\mathrm{F}\left[E^{\mathrm{o}}\left(\mathrm{QH}^{+/ 0}-E^{\mathrm{o}}\left(\mathrm{HNO}^{0 /-}\right)\right]\right.
$$

Further insight is obtained by application of the Nernst relationship, Equation 5, utilizing the reported potentials vs NHE for quercetin oxidation $(0.26 \mathrm{~V})$ and HNO reduction $(-0.22 \mathrm{~V}){ }^{22-}$ ${ }^{24}$ which obtains the theoretical energy for single electron transfer (SET) of $11.0 \mathrm{kcal} / \mathrm{mol}$. This value is quite close to that of the determined $\Delta G^{\ddagger}$ for the non-enzymatic nitroxygenation, and thus is consistent with an initial SET as the rate-determining step. One product of SET would be $\mathrm{HNO}^{-}$, the aminoxyl radical anion, at an estimated reduction potential of $0.52 \mathrm{~V} \mathrm{NHE},{ }^{25}$ as compared to that of superoxide at $-0.33 \mathrm{~V}$ from $\mathrm{O}_{2}$, which would be required for dioxygenation by SET. ${ }^{26}$ Thus the accelerated rate of nitroxygenation vs. oxygenation can be attributed to the difference in driving force in the SET rate-determining step.

\section{Scheme 3}
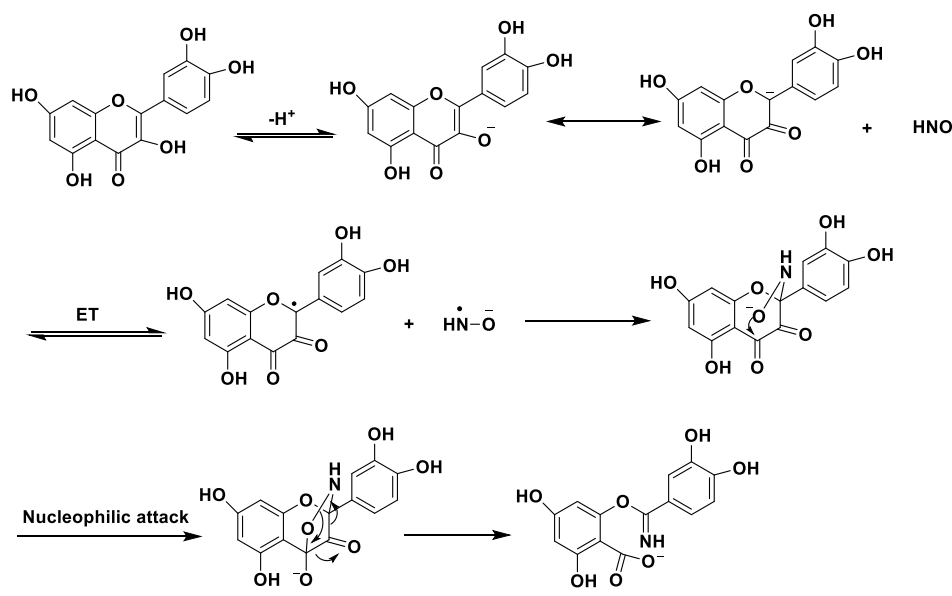

These results are consistent with the proposed mechanism shown in Scheme 3. In this sequence, quercetin is first deprotonated, generating an anion with substantial electron density located on $\mathrm{C} 2$ of the central ring. The rate-limiting electron transfer between quercetinate and $\mathrm{HNO}$ produces a quercetin radical and the aminoxyl radical anion, $\mathrm{HNO}^{-}$. Radicalradical coupling generates an $\mathrm{N}$-oxyamino anion; this key intermediate may also be generated by nucleophilic attack of a C2-based carbanion on HNO, analogous to the nitroso aldol reactions. But the relatively small entropy of activation suggest no bond formation in the rate-determining step, thus supporting the outersphere SET mechanism. ${ }^{27,28}$ The incipient N-oxyamino anion then undergoes an intramolecular nucleophilic attack at the C4 carbonyl, releasing $\mathrm{CO}$ and forming the proposed depsidic intermediate which decomposes to the observed products.

Conclusion. The nitroxygenation of quercetin with HNO is much more facile than the comparable dioxygenation, some 1000-fold faster at room temperature than an analogous dioxygenation at $70{ }^{0} \mathrm{C}$. Thermodynamic analysis yields an activation barrier very similar to that predicted for a ratedetermining SET step; the difference in rates may be attributed to a large difference in SET driving force. The unique regioselectivity of nitroxygenation may be of use in organic synthesis, as well as to provide mechanistic insight in comparison to analogous dioxygenation reactions.

Acknowledgments. This research was supported by the National Science Foundation (PJF CHE-1057942).

\section{References}

1. Dragsted, L.; Strube M.; Larsen, J. Pharmacology \& Toxicology. 1993, 72, 116-135.

2. Bors, W.; Heller, W.; Stettmaier K. Handbook of Antioxidants. 1996, 409-466

3. Shahidi F. and Wanasundara P. Critical Reviews in Food Science and Nutrition. 1992, 32, 67-103.

4. a) Schaab, M. R.; Barney, B. M.; Francisco, W. A. Biochemistry, 2006, 45, 1009-1016. b) Fusetti, F.; Schroter, K. H.; Steiner, R. A.; Noort, P.; Pijing, T.; Rozeboom, H. J.; Kalk, K. H.; Egmond, M. R.; Dijkstra, B. W. Structure, 2002, 10, 259-268. c) Gopal, B.; Madan, L. L.; Betz, S. F.; Kossiakoff, A. A. Biochemistry, 2005, 44, 193-201.

5. a) Hergovich, E. B. and Speier G. J. Org. Chem. 2001, 66, 79747978. b) Czaun, M.; Speier, G. Tetrahedron Lett. 2002, 43, 59615963. c) Czaun, M.; Speier, G.; Kaizer, J.; Farkas, E. Tetrahedron 2013, 69, 6666-6672.

6. a) Pap, J. S.; Kaizer, J.; Speier, G. Coord. Chem. Rev., 2010, 254, 781-793. b) Balogh-Hergovich, E.; Speier, G.; Argay, G. J. Chem. Soc. Chem. Commn., 1991, 551-552. c) Matuz, A.; Giorgi, M.; Speier, G.; Kaizer, J. Polyhedron, 2013, 63, 41-49. d) Lippai, I.; Speier, G. J. Mol. Cata. A:, 1998, 130, 139-148. e) BaloghHergovich, E.; Kaizer, J.; Speier G.; Hutter, G.; Jacobi, A. Inorg. Chem., 2000, 39, 4224-4229. f) Balogh-Hergovich, E.; Kaizer, J.; Sperier, G.; Fulop, V.; Parkanyi, L. Inorg. Chem. 1999, 38, 37873795.

7. a) Grubel, K.; Rudzka, K.; Arif, A. M.; Klotz, K. L.; Halfen, J. A.; Berreau, L. M. Inorg. Chem., 2010, 49, 82-96. b) Berreau, L. M.; Borowski, T.; Grubel, K.; Allpress, C. J.; Wikstrom, J. P.; Germain, M. E.; Rybak-Akimova, E. V.; Tierney, D. L. Inorg. Chem., 2011, 50, 1047-1057. c) Szajna-Fuller, E.; Rudzka, K.; Arif, A. M.; Berreau, L. M. Inorg. Chem., 2007, 46, 5499-5507. d) Grubel, K.; Fuller, A. L.; Chambers, B. M.; Arif, A. M.; Berreau, L. M. Inorg. Chem., 2010, 49, 1071-1081.

8. a) Nishinaga, A.; Tojo, T.; Matsuura, T. J. Chem. Soc., Chem. Commun. 1974, 896-897. b) Nishinaga, A,; Numada, N.; Maruyama, K. Tetrahedron Lett. 1989, 30, 2257-2258. C) Nishinaga, A.; Kuwashige, T.; Tsutsui, T.; Mashino, T.; Maruyama, K. J. Chem. Soc., Dalton Tran. 1994, 805-810.

9. Kumar, M.; Zapata, A.; Ramirez, A.; Bowen, S.; Francisco, W.; Farmer, P. Proc. Natl. Acad. Sci. 2011, 108, 18926-18931.

10. Demaster, E. G.; Redfern, B.; Nagasawa, H. T. Biochem. Pharmacol. 1998, 55, 2007-2015.

11. Momiyama, N.; Yamamoto, H. Chem. Commun. 2005, 3514.

12. Lewis, J.W.; Meyer, P. L.; Ormerod, J. A. J. Chem. Soc., Perkin Trans. 1972, 20, 2521-2524.

13. Sasaki, T.; Ishibashi, Y.; Ohno, M. Chem. Lett., 1983, 12, 863866.

14. Sasaki, T.; Mori, K.; Ohno, M. Synthesis, 1985, 3, 280-282.

15. Momiyama, N.; Yamamoto, H. Org. Lett., 2002, 4, 3579-3582.

16. Kawasaki, M.; Li, P.; Yamamoto, H. Angew. Chem. Int. Ed., 2008, 47, 3795-3797.

17. Momiyama, N.; Yamamoto, H. J. Am. Chem. Soc., 2005, 127, 1080.

18. Lunte, C.; Sanli, S. Anal. Methods, 2014, 6, 3858-3864. 
19. (a) Shafirovich, V.; Lymar. S. J. Am. Chem. Soc. 2003, 125, 65476552. (b) Lymar, S. V.; Shafirovich, V.; Poskrebyshew, G. A. Inorg. Chem. 2005, 44, 5212-5221.

20. REACT for Windows, Version 1.2; Manka, M. J., Ed.; Alchemy Software, Wesley: Chapel, FL, 2001; as described in Braun, W.; Herron, J. T.; Kahaner, D.K. Int. J. Chem. Kinet. 1988, 20, 51-62.

21. Schaab, M. R.; Barney, B. M.; Francisco, W. A. Biochemistry, 2006, 45, 1009-1016.

22. Shafirovich V. and Lymar S. V. Proc. Natl. Acad. Sci. 2002, 99, 7340-7345.

23. Yang B.; Kotani A.; Arai, K.; Kusu, F. Anal. Sci. 2001, 17, 599604.

24. Yang B.; Arai K.; Kusu F. Anal. Sci. 2001, 17, 987-989.

25. Lind, J.; Merenyi, G. J. Phys. Chem. A 2006, 110, 192-197.

26. Wood, P.M. Biochem. J. 1988 253, 287-289.

27. Han X. Z.; Parker, V. D. and Zhu, X. Q. J. Org. Chem. 2012, 77, 6520-6529.

28. (a) Page, M.; Williams, A. Organic and Bio-organic Mechanism; Longman: Harlow, UK, 1997; Chapter 3, pp. 52-79. (b) Williams, A. Acc. Chem. Res. 1984, 17, 425-430. (c) Williams, A. Acc. Chem. Res. 1989, 22, 387-392. (d) Williams, A. Adv. Phys. Org. Chem. 1991, 27, 1.(e) Williams, A. J. Am. Chem. Soc. 1985, 107, 6335-6339. 


\section{Graphical Abstract}

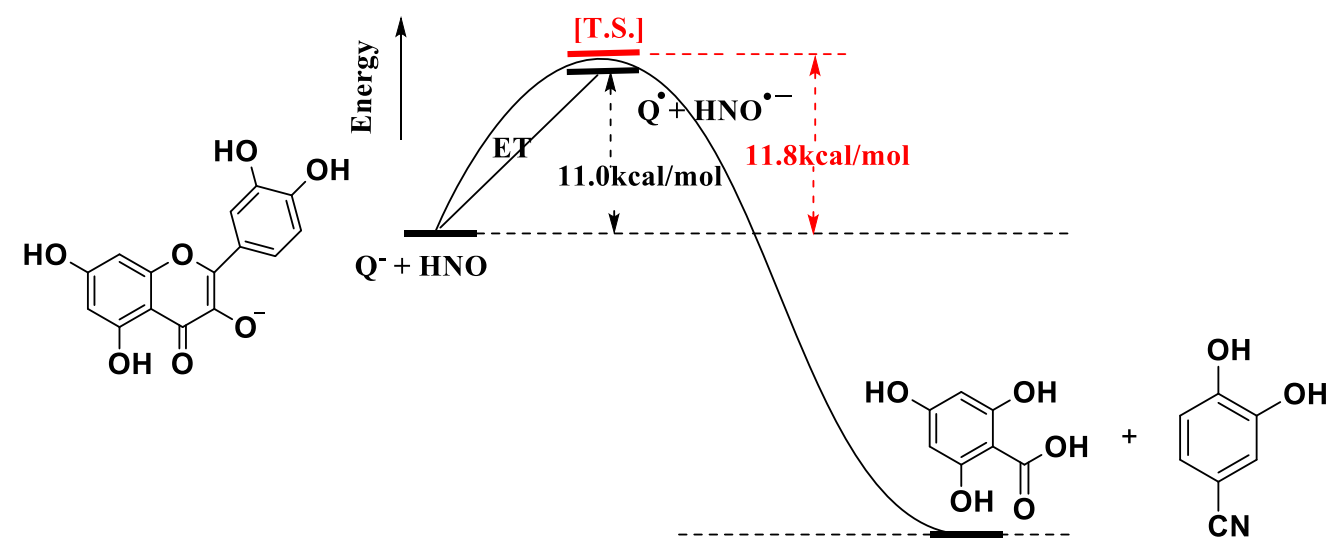

